\title{
HEDGES, POLITENESS STRATEGIES, AND POWER: A CASE OF WOMEN COMMUNITY LEADER IN MALANG REGENCY
}

\author{
Asih Zunaidah \\ Faculty of Economic \& Comunication, Binus University \\ Email: asih.zunaidah@binus.ac.id
}

\begin{abstract}
Abstrak
Speech pattern terkait gender dan kekuasaan telah lama menjadi fokus dalam penelitian komunikasi. Perempuan dan kekuasaan dulunya berada pada polar yang berbeda. Hal inilah yang menarik untuk diteliti: apakah menjadi seorang pemimpin wanita menunjukkan adanya 'perlawanan' terhadap asumsi speech pattern seorang wanita. Studi kasus ini dilaksanakan pada para pemimpin perempuan sebuah komunitas sosial 'Pelangi Nusantara'. Penelitian ini berfokus pada speech mereka untuk meneliti stereotip speech pattern yang terkait dengan penggunaan hedges dan strategi kesantunan penutur wanita yang memiliki kekuasaan. Penelitian ini menggunakan pendekatan deskriptif kualitatif serta teknik purposive untuk menentukan subyek yang diwawancarai. Berdasarkan analisis, terungkap bahwa meskipun memiliki posisi tinggi (kekuasaan) di masyarakat, sebagian besar subyek penelitian menunjukkan stereotip speech pattern melalui penggunaan hedges, strategi kesantunan, dan konvergensi; hal ini dipengaruhi oleh latar belakang budaya.
\end{abstract}

Kata Kunci: CAT, hedges, kekuasaan, pemimpin wanita, strategi kesantunan

\begin{abstract}
Gender and power related speech patterns have been a focus of communication studies. Women and power used to be in opposite side of each other. On this ground, we were intrigued to investigate whether being a female leader has something to do with defying certain assumed ideals of women speech. This case study was conducted to women leaders engaged in a social community called Pelangi Nusantara. Concerning this study, we focused on the women leaders' speech to examine the stereotyped-speech-pattern related to the use of hedges and politeness strategies in female speakers albeit holding a high position. A descriptive qualitative approach was employed along with the purposive technique to select the interviewees. Based on the analysis, it is revealed that despite holding a high position in the community, the female leaders mostly showed the stereotyped-speech-pattern through the use of hedges, convergence, and politeness strategies as influenced by their cultural background.
\end{abstract}

Keywords: CAT, female leaders, hedges, politeness strategies, power 


\section{INTRODUCTION}

In a communicative fashion, gender has long been associated with particular linguistic traits displaying women and men distinctive characteristics. As a taking-off point for our study, we reviewed how Lakoff (1975) and Fairclough (1989) scrutinized language use and its relation to gender and power respectively. For the past decades, researchers have long paid attention to how people define the way women and men should speak, also to how power take part in language use, which is naturally varied across the globe and contingent on the culture. Despite living in a modern era in which gender-equality bandwagon is in force, we do correspond with, to a certain degree, language patterns conformable to gender stereotyping. The patterns are constituted of certain features attributed to male or female language user; to exemplify, previous research revealed that men tend to speak directly while it is common for women to attenuate their expressions, albeit not entirely (Abbou, 2016; Mohindra and Azzar, 2012; Pan, 2011).

As girls and boys, we were 'taught' to be aware of people's disapproval since we were kids, and this lasts until we become adults. Girls have been discouraged to practice 'rough talk' because it is 'not girly', while it is normal for boys to talk this way as it depicts masculinity. In contrast, if boys were being sweet and soft, they would be ridiculed for being unmanly (Lakoff, 1975). Nevertheless, this view is indubitably bias to cultural construction. It is social and cultural norms that regulate men and women in their choice of language use for communicating; thus, language allows us to investigate a few aspects in culture as cultural values and norms are the most undynamic aspects in society as they have been incorporated to the people's lives for generations.

This study was conducted in Malang Regency, East Java; it is, therefore, the Javanese people who were the subjects of our research. As a departure point, it is essential to discuss the nature of Javanese culture. Hofstede (in Nadar, 2007) categorized Javanese culture into high-collectivism and low-individualism; he suggested that the community thinks highly of their togetherness and are very conscious of what may reduce the quality of their closeness. Moreover, indirectness is a crucial element of Javanese culture; being direct is not a preferable way of interpersonal communication. The Javanese people avoid making someone feel bad by saying things directly and it is better to conceal their true intention especially if it may contradict to other people's wish; in Javanese culture, straightforwardness in interactions is often undesirable (Wierzbicka, in Nadar, 2007). Moreover, quoting Hefner (2008), an ethnographic research in East Java indicated that Javanese women are demanded to be speak more politely if married to a family, albeit receiving less polite speech. At some point, this instilled cultural and social value affects how Javanese women act and talk

Javanese society is known to be patriarchal, in which men are more dominant than women in many aspects of life. The women are perceived as having lower status than men and associated with 'powerlessness'; among women's ideal traits are being obedient, polite, and refined, both reflected through their behavior and language. In their textbooks, school children in Indonesia have been reading sentences such as 'Ayah membaca koran, dan Ibu memasak di dapur' (the father is reading a newspaper, and the mother is cooking in the kitchen) for decades. This indicates that patriarchal values have been indoctrinated at a very 
early stage of life; thereby, as adults, it is not uncommon for us to conform to these preconceived perceptions of what is deemed proper.

Another concept discussed in this study is the relation between power and language use; power, in this context, refers to holding a high position in an organization or a community. Fairclough (1989) asserted that holding power means one is able to enforce and maintain particular domain's structuring. Moreover, language remains a part of what reflects power and language speakers are involved in power relation; this exists between a leader and his subordinates, between an employer and his employees, between parents and their children, between men and women, and many more. Power, in a discourse, involves 'unequal' participants: one is regarded more powerful than the other. A number research reveal that power differences between interlocutors affect turn-takings, directness, and choice of words (Karlberg, 2005; Wodak, 2012; Mizil, et.al., 2011).

Pertaining to this study, what sparked our interest was how women with power communicated within a discourse. The question raised was whether holding a power means that women would contravene the 'obsolete' stereotypes associated with them; the stereotypes discussed in the context are related to language: the use of politeness strategies and hedges (as parts of the convergence strategy), which are known to be features attributed to women almost globally. Some previous studies reveal that these two were closely associated with women (Rosanti and Jaelani, 2015; Shafiee and Namaziandost, 2018; Dousti and Rasekh, 2016). Repectively, 'convergence' and 'divergence' have been comprehensively studied and considered as the historical core of the CAT (Giles and Ogay, 2007). Convergence is defined as a strategy by which individuals adapt their communicative behaviors in various linguistic, paralinguistic, and nonverbal features, to resemble more of their conversational partner's behavior. On the contrary, the 'divergence' strategy emphasizes speech and nonverbal dissimilarity between or among individuals.

Moving on to the notion of politeness strategies, the concept of face and FTA (Face Threatening Act) were put forward by Brown \& Levinson as a starting point. 'Face' here refers to one's social self-esteem. The theory discusses certain kinds of acts threatening face, namely those acts considered contrary to the "face want" of the addressee and/or the speaker (Brown \& Levinson, 1978, 1987). In this case, "act"e can be both verbal and non-verbal communication. In their notion, one would rationally look for a way to avoid doing any FTA or use certain strategies to minimize the threat (in verbal communication), as schematized in Figure 1 (Brown \& Levinson, 1978, 1987):

Figure 1. Strategies in doing FTA

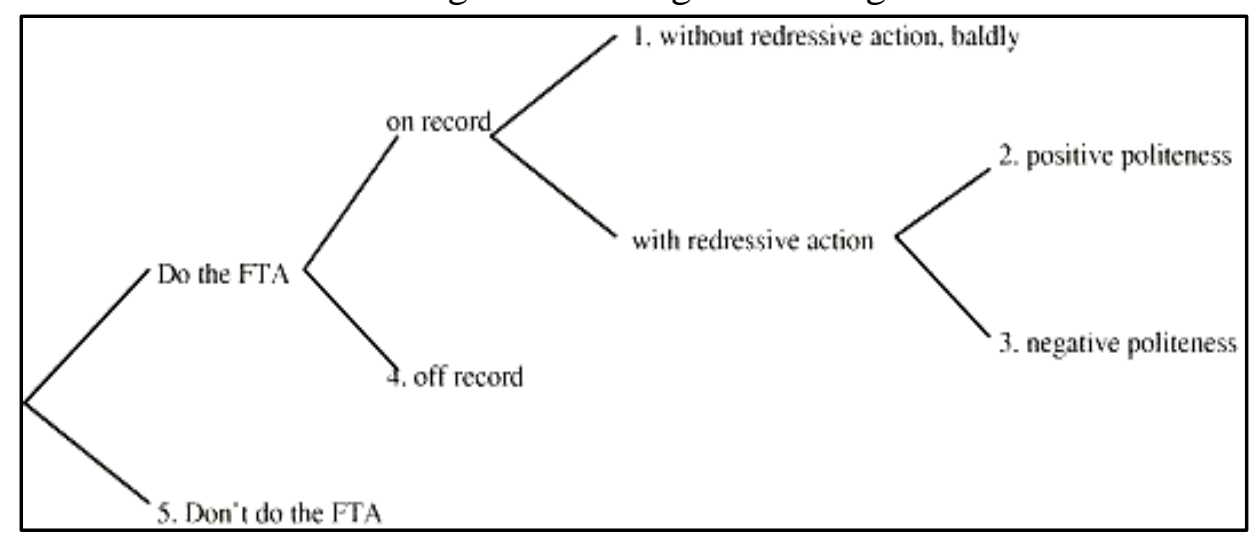


The next theory used in this study is the linguistic hedges. In a spoken interaction, speakers use certain expressions to indicate that the utterance might not be fully accurate; these cautious notes are called 'hedges' (Yule, 1996). Some examples of hedges are inserting 'sort of', 'maybe', 'you know', 'I think', 'somehow', etc. In politeness strategies, hedges are used to make the speaker's opinion safely vague and have a better chance of being accepting, also to minimize any risky disagreements (Brown and Levinson, 1978, 1987). The types of hedges are approximators, shield, and intensifiers (Quirk and Greenbaum, in Ewata, 2017).

As aforementioned, this case study particularly discusses the Javanese women. The subjects involved in this case study were the women leaders of a social community called 'Pelangi Nusantara' or abbreviated as Pelanusa - a social-entrepreneur-based community attempting to help empower Malang Regency women in increasing their family income through creating various crafts and selling them. We investigated whether these 'powerful' women defied the preconceived notions of having to use certain politeness strategies and hedges in verbal interactions for displaying the proper 'Javanese women language'. Accordingly, this study is expected to contribute to the enrichment of communication or linguistic studies related to women, power, and their relation to language in verbal communication.

\section{RESEARCH METHODS}

This is a case study employing a qualitative approach. In a qualitative research, it is essential to take social context into account for understanding the social world (Neuman, 1997); in that, the meaning of a social action or event greatly relies on the context in which it occurs. This implies that the same event or behavior might not have the same meaning in different contexts or cultures. Pertaining to a case study, Neuman pointed out that a case study researcher gathers information on one or few cases and goes into a greater depth to obtain the details of the case being investigated. The immersion of the analysis process allows the researcher to have intimate familiarity with people's live and culture; he examines the patterns in the people's lives, actions, and words in the context of the complete case as a whole.

This research was conducted in Malang Regency, East Java. 7 women leaders of the Pelanusa community were purposively sampled as they were the most active group leaders in the community, one of whom was the founder. The data were collected through 6-months observations and in-depth interviews. In the process, their spoken interactions delivered in Indonesian (sometimes combined with Javanese) with the community's founder, fellow leaders, and members were observed. The questions asked in the interviews were related to their communication with the founder or the leaders as well as things related to the community (income, problems and obstacles). For ensuring the validity and reliability of data analysis, the triangulation technique was used in which source and theories were involved. The data were interpreted to make them understandable since interpretation in a qualitative is to learn the meaning of the data for the people being studied and their motives in doing their actions. It was started by transcribing the interview responses, examining the 
data obtained from observations, and selecting the suitable information related to the research purpose. From this point, the data were analyzed using the related theories (convergence-divergence, hedges, and politeness strategy theoris), and finally, the results were presented and discussed.

\section{RESULTS AND DISCUSSION}

After conducting a thorough analysis on the data obtained, the results are presented in Table 1:

Table 1. The Analysis Results of Hedges, Politeness and Communication Strategies Used by the Women Leaders

\begin{tabular}{|c|c|c|c|c|c|c|}
\hline \multirow[b]{2}{*}{ SPEAKER } & \multirow[b]{2}{*}{ HEDGES } & \multicolumn{3}{|c|}{ POLITENESS STRATEGY } & \multicolumn{2}{|c|}{$\begin{array}{c}\text { COMMUNICATION } \\
\text { STRATEGY }\end{array}$} \\
\hline & & $\begin{array}{c}\text { Bald } \\
\text { on } \\
\text { Record }\end{array}$ & $\begin{array}{c}\text { Positive } \\
\text { Politeness }\end{array}$ & $\begin{array}{l}\text { Negative } \\
\text { Politeness }\end{array}$ & Convergence & $\begin{array}{c}\text { Divergenc } \\
\mathrm{e}\end{array}$ \\
\hline Founder & $\checkmark$ & $\checkmark$ & $\checkmark$ & $\checkmark$ & $\checkmark$ & $\checkmark$ \\
\hline Leader 1 & $\checkmark$ & & $\checkmark$ & & $\checkmark$ & \\
\hline Leader 2 & $\checkmark$ & & $\checkmark$ & & $\checkmark$ & \\
\hline Leader 3 & $\checkmark$ & $\checkmark$ & $\checkmark$ & $\checkmark$ & $\checkmark$ & $\checkmark$ \\
\hline Leader 4 & $\checkmark$ & & $\checkmark$ & $\checkmark$ & $\checkmark$ & \\
\hline Leader 5 & $\checkmark$ & & $\checkmark$ & & $\checkmark$ & \\
\hline Leader 6 & $\checkmark$ & & $\checkmark$ & $\checkmark$ & $\checkmark$ & \\
\hline
\end{tabular}

From the table, it appears that all subjects used hedges as a part of their utterances. The commonly used hedges were the approximators such as biasanya (usually/ generally), sekitar (about/ around/ more or less), gak seberapa (a bit/ a little), lumayan (fairly/ quite), kadang-kadang (sometimes/ occasionally), and kayak (sort of/ kind of). The following dialogues are some examples of the speakers using hedges:

a) Interviewer: Ini panjenengan selalu datang ke pertemuan rutin nggih, Bu?

(So, you always attend the regular gathering, right Ma'am?)

Leader 1: Ya... lumayan mbak, kadang juga gak bisa soalnya jadwalnya terapi.

(Well, quite so, sometimes I can't attend the gathering due to my therapy schedule)

b) Member: Mbak Nik, ini bener ya? Kudu dijahit sekalian tho? 
(Mbak Nik, is this correct? I should sew them altogether, right?)

Leader 2: Sek mbak ojo dhisik, biasane topinya itu dijahit belakangan ben ketok lebih rapi.

(Hold it mbak, the hat is usually sewed later to make it more seamless)

Hedges are multiculturally used as it can always be a strategy to minimize disagreement or making mistakes by being vague. In the examples, the first speaker (leader 1) used the hedge 'lumayan' (quite so) to avoid the answer 'no' and keep it in the approximation: not always, but fairly regular. The dialogue took place in an interview with one of the researchers. The second dialogue shows the use of 'biasane' (usually); in this utterance, the speaker avoids making incorrect judgement by answering with 'yes/ no' although she was an experienced leader and tutor in sewing bags. This hedge is useful for making uncertain decision or opinon. The context of this dialogue is between a leader with one of her members; it occurred in the community gathering and they were making a bag.

The next analysis discusses the use of politeness strategies, which is illustrated by the following utterances:

a) Bald on Record

Founder: Mbak, aku mau sing podo ae (suvenir) karo liyane, ndak usah dibedakan.

(Mbak, I want the same souvenir as the others, don't make me special)

The context of this utterance was when the founder was told (by one of the researcher) that she would receive a special souvenir from the researchers as she was the founder. In the utterance, she directly asked for the same souvenir and refused to be specialized. This is a clear example of a 'bald on record' strategy.

\section{Leader 3: $\underline{\text { Jawab }}$ sing iki (pertanyaan), mbak. Sampeyan kakehan bukanya, wong} sekarang sek di halaman 4.

(Answer this one (question), mbak. You miss one page, we're still in page

This utterance was recorded when the researchers asked the leaders and members to answer a questionnaire (for other purposes, and not used in this research). The context of this utterance was when the speaker saw a member (sitting next to her) opened the wrong page. She directly ordered the member to answer the questions in the previous page.

\section{b) Positive Politeness}

Leader 2: Jadi ini caranya kita jahit dulu, gak usah rapet gak apa-apa, nanti bisa dilepas lagi.

(So first we sew this, no need for tight stitch, we can undo it later)

This utterance was recorded in a gathering. The members were making a bag and the leaders were tutoring them. In the example, the leader used 'we' as an inclusive form of pronoun when she was actually referring to 'you'. This is a positive politeness in which strategy is to includde bot interlocutors in the activity. 
Leader 5: Oke, sudah bagus mbak, tapi tolong dirapikan lagi dikit ya.

(Okay, it's good, but please make it a bit more seamless)

This is another utterance recorded in a gathering. The community members were sewing a decorative patch on a piece of fabric. The context was when the leader was asked for her opinion about a member's work. By saying 'it's good, but...', she applied a positive politeness strategy through stating a 'token agreement', or pretending to agree. Rather than blatantly sayin 'no, it's not good', she twisted her utterance to hide her disagreement.

c) Negative Politeness

Leader 4: Apa ndak lebih bagus pakai warna yang ini ae, mbak? Biar kelihatan luwih jreng?

(Don't you think it's better to use this color, mbak? To make it more vibrant?)

The context of this utterance was when a member asked her leader about her choice of color. In this negative politeness strategy, an indirect speech act was used. The real purpose of her question was to give a suggestion, but she avoided imposing on the interlocutor's negative face.

\section{Leader 6: $B u$, panjenengan nopo mau berangkat sekarang?}

$(B u$, are you leaving now?)

In this utterance, the speaker was talking to the founder of the community. She addressed the lady with a Javanese honorific 'panjenengan'. In fact, almost all of the group leaders and members addressed the founder this way. In Javanese, it is used when addressing someone older than us or someone highly respected. The use of honorifics is included in a negative politeness strategy.

Finally, we have come to the next discussion: communication strategy. Essentially, a convergence strategy is used for shortening the social-distance while divergence is the opposite, as it is used for establishing power or dominance. Convergence is commonly found in an interaction in which the speaker has a lower status than the hearer, as opposed to divergence. Based on the results in Table 1, all subjects of this study practiced the convergence strategy in different contexts. Convergence is closely associated to the positive politeness strategy: the speaker wants to be accepted and close to the addresse. The founder, though being in the highest position in the community, applied convergence quite frequently when she communicates in informal contexts. This suggests that she needs to maintain closeness and friendliness with her members. Additionally, the same strategy was practiced by the group leaders; it is common to see them communicate with other leaders and their members using positive politeness strategies (and of course, convergence). The divergence strategy, however, was rarely found in the data. Only a few times did the founder and one of the leaders use this strategy, such as in meetings or instructional (formal) contexts, while the rest of the leaders did not. 
Based on the results, it is safe to say that holding power does not necessarily change the way these Javanese women leaders communicate with those of lower position in the community. As they live in a modern time, it is easy for them to be exposed with the world and foreign cultures through the use of smartphones and the internet. The worldwide media show it is okay for women to act and speak impolitely or not-lady-like; in brief, it is okay to speak your mind and be direct without worrying certain cultural values. Nevertheless, as seen from the results, the Javanese values of being indirect, polite and refined are still reflected through the women leaders' action and language; thus, convergence and positive politeness strategies remain at the top position. It seems that these women are not affected by how modern women are depicted in the media; therefore, it is true that deep-rooted values of a culture is hard to change, even in this disruptive era. Provided that people live in a neighborhood preserving its cultural values, such as the subjects in this study, they will still adhere to and practice the strongly indoctrinated values despite any influences coming from outside their circle.

\section{CONCLUSION}

To conclude, the results reveal that all subjects used linguistic hedges at some point in their conversations as a part of their communication strategy. Hedge is a cautious language use; it maintains the speaker in a safe position of not to impose face threats and potential disagreements. This is included in the positive politeness strategies, which are practiced by all of the subjects as a part of performing the convergence strategy. This study proves that indirectness and politeness are indeed prominent parts of the Javanese culture.

From the results, only a few subjects showed the use of bald on record and negative politeness strategies in doing FTAs. Even if the interlocutors were on a lower position than the speakers, this does not make them abandon the value of being indirect and polite. Rarely did the women leaders impose FTAs directly, also established their power and dominance through the divergence strategy; this occurs when they were in formal meetings or instructional contexts (such as tutoring or supervising the creation of crafts) as it is crucial to control and maintain the quality of the products created by the members.

Lastly, we recommend further research on Javanese women leaders living in other areas of Java; presumably, the research can support the findings of this study or even have different findings, for different area and different age range might contribute to distinctive results.

\section{REFERENCES}

Brown and Levinson. 1978, 1987. Politeness: Some Universals in Language Use. Cambridge: Cambridge University Press.

Ewata, Olusegun Thompson. 2017. Linguistic Hedging: Conflict Management Tool in Academic Discourse. Modern Research Studies. Vol.4, 536-554.

Giles, H., \& Ogay, T. (2007). Communication Accommodation Theory. In B. B. Whaley \& W. Samter (Eds.), Explaining communication: Contemporary theories and exemplars 
(pp. 293-310). Mahwah, NJ: Lawrence Erlbaum.

Nadar, FX. 2007. The Prominent Characteristics of Javanese Culture and Their Reflections in Language Use. Jurnal Humaniora. 19(2), 168-174.

Lakoff, R. (1975). Language and Women's Place. New York: Harper \& Row.

Neuman, W.L. (1997). Social Research Methods: Qualitative and Quantitative Approaches. 3rd Edition, Allyn and Bacon, Boston.

Norman Fairclough, Language and power. London: Longman. 1989

Rahmawati, Risti Yani. Hedging Devices Used in "Room For Debate” in New York Times Online Website. A Master Thesis. 2016.

Smith-Hefner, N. (1988). Women and Politeness: The Javanese example. Language in Society, 17(4), 535-554. doi:10.1017/S0047404500013087.

Turner, L., and Turner and West, R.2008. Pengantar Teori Komunikasi: Analisis dan Aplikasi. Buku 1 dan 2. Jakarta: Salemba Humanika.

Yule, George. 1996. Pragmatics. Oxford University Press: Oxford. 